\title{
The DExD/H-box ATPase Prp2p destabilizes and proofreads the catalytic RNA core of the spliceosome
}

\author{
ALISSA M. WLODAVER and JONATHAN P. STALEY ${ }^{1}$ \\ Department of Molecular Genetics and Cell Biology, The University of Chicago, Chicago, Illinois 60637, USA
}

\begin{abstract}
After undergoing massive RNA and protein rearrangements during assembly, the spliceosome undergoes a final, more subtle, ATPdependent rearrangement that is essential for catalysis. This rearrangement requires the DEAH-box protein Prp2p, an RNAdependent ATPase. Prp2p has been implicated in destabilizing interactions between the spliceosome and the protein complexes SF3 and RES, but a role for Prp2p in destabilizing RNA-RNA interactions has not been explored. Using directed molecular genetics in budding yeast, we have found that a cold-sensitive prp2 mutation is suppressed not only by mutations in SF3 and RES components but also by a range of mutations that disrupt the spliceosomal catalytic core element U2/U6 helix I, which is implicated in juxtaposing the $5^{\prime}$ splice site and branch site and in positioning metal ions for catalysis within the context of a putative catalytic triplex; indeed, mutations in this putative catalytic triplex also suppressed a prp2 mutation. Remarkably, we also found that prp2 mutations rescue lethal mutations in U2/U6 helix I. These data provide evidence that RNA elements that comprise the catalytic core are already formed at the Prp2p stage and that Prp2p destabilizes these elements, directly or indirectly, both to proofread spliceosome activation and to promote reconfiguration of the spliceosome to a fully competent, catalytic conformation.
\end{abstract}

Keywords: DExD/H-box ATPase; Prp2; U2/U6 helix I; spliceosome activation; spliceosome catalytic core

\section{INTRODUCTION}

Most eukaryotic genes are interrupted by introns, which must be excised from pre-mRNA for proper gene expression (Wahl et al. 2009). The chemistry of this pre-mRNA splicing reaction is a relatively simple sequence of two transesterification reactions, first between an adenosine in the branch point sequence and the $5^{\prime}$ splice site ( $5^{\prime}$ splice site cleavage) and then between the $5^{\prime}$ splice site and the $3^{\prime}$ splice site (exon ligation). These reactions are catalyzed by the spliceosome, an RNA-protein assembly of 80 conserved proteins and five small nuclear RNAs (snRNAs): U1, U2, U4, U5, and U6 (Wahl et al. 2009). The spliceosomal snRNAs recognize the consensus sequences of the intron at the $5^{\prime}$ splice site and the branch site, and subsequently during spliceosome activation, the snRNAs form key structures that compose the catalytic core of the spliceosome. These structures include the U2/U6 helix I (Madhani and Guthrie 1992; Sun and Manley 1995; Mefford and Staley 2009), composed of U2/ U6 helix Ia, which juxtaposes the reactants for the first step of splicing, and U2/U6 helix Ib (Madhani and Guthrie 1994b; Hilliker and Staley 2004; Mefford and Staley 2009),

\footnotetext{
${ }^{1}$ Corresponding author

E-mail jstaley@uchicago.edu

Article published online ahead of print. Article and publication date are at http://www.rnajournal.org/cgi/doi/10.1261/rna.042598.113.
}

which, together with residues in the U6 intramolecular stem-loop (ISL), has been shown to position catalytic metal ions, similar to the catalytic domain $\mathrm{V}$ of the self-splicing group II intron (Fabrizio and Abelson 1992; Yu et al. 1995; Yean et al. 2000; Toor et al. 2008; Koodathingal et al. 2010; Fica et al. 2013). Before the catalytic activation of the spliceosome, these key structures are precluded by mutually exclusive base-pairing interactions between U6 and U4 snRNAs (Brow and Guthrie 1988; Madhani and Guthrie 1992). Unwinding of the U4/U6 duplex during spliceosome activation provides the potential to form these catalytic components, but it is not yet known when these catalytic features form.

Spliceosome assembly and activation occur de novo on each pre-mRNA and follow an elaborate pathway involving dramatic RNA and protein rearrangements (Wahl et al. 2009). Numerous steps in this pathway require ATP hydrolysis by $\mathrm{DExD} / \mathrm{H}$-box ATPases; in several cases, these factors have been shown additionally to promote the fidelity of splicing through kinetic proofreading mechanisms (Semlow and

\footnotetext{
(C) 2014 Wlodaver and Staley This article is distributed exclusively by the RNA Society for the first 12 months after the full-issue publication date (see http://rnajournal.cshlp.org/site/misc/terms.xhtml). After 12 months, it is available under a Creative Commons License (Attribution-NonCommercial 3.0 Unported), as described at http://creativecommons.org/licenses/by$\mathrm{nc} / 3.0 /$.
} 
Staley 2012). DExD/H-box ATPases make up a large protein family of about 50 members that participate in nearly all aspects of RNA metabolism throughout the cell, and they are found in all kingdoms of life (Putnam and Jankowsky 2013). The range of fundamental, biochemical activities of $\mathrm{DExD} / \mathrm{H}$-box ATPases includes the unwinding of RNA duplexes, the disruption of RNA-protein complexes, and the assembly of RNA-protein complexes (Linder and Jankowsky 2011). Indeed, several spliceosomal DExD/H-box ATPases have been implicated in unwinding specific RNA duplexes or to disrupt specific RNA-protein interactions (Schwer and Guthrie 1992; Fleckner et al. 1997; Kim and Rossi 1999; Staley and Guthrie 1999; Perriman et al. 2003; Hilliker et al. 2007; Perriman and Ares 2007, 2010; Schwer 2008; Mefford and Staley 2009). However, the biological roles of many DExD/H-box ATPases remain poorly understood.

The DEAH-box ATPase Prp2p functions at a late stage of spliceosome activation (Kim and Lin 1993, 1996). Indeed, Prp2p functions in the final ATP-dependent step necessary for $5^{\prime}$ splice site cleavage (Fig. 1A). In this final step, Prp2p promotes conversion of the spliceosome from a pre-catalytic conformation into a catalytic conformation. Like most other spliceosomal DExD/H-box ATPases, the association of Prp2p with the spliceosome is transient (King and Beggs 1990). When Prp2p activity is required during spliceosome activation, $\operatorname{Prp} 2 \mathrm{p}$ is recruited to the spliceosome through its interaction with the G-patch protein Spp2 and then, after ATP hydrolysis by Prp2p, both factors dissociate (Roy et al. 1995; Kim and Lin 1996; Silverman et al. 2004; Fabrizio et al. 2009). Like many other $\mathrm{DExD} / \mathrm{H}$-box ATPases, the ATPase activity of Prp2p is stimulated by RNA binding (Kim et al. 1992). Prp2p cross-links to pre-mRNA downstream from the branch site, and this region of the substrate is required during spliceosome activation, so it has been proposed that Prp2p could destabilize interactions involving the pre-mRNA near the branch site (Teigelkamp et al. 1994; Liu and Cheng 2012). Indeed, recent studies have begun to elucidate the hallmarks of the role of Prp2p in activation as characterized by protein dynamics at the branch site. Proteomics studies have implicated Prp2p in destabilizing the spliceosomal association of the U2 snRNP complex SF3, the RES complex, and the NTC-related proteins Cwc24p and Cwc27p, although not necessarily in dissociation of these factors (Bessonov et al. 2008; Fabrizio et al. 2009; Warkocki et al. 2009; Lardelli et al. 2010; Agafonov et al. 2011; Ohrt et al. 2012), with the destabilization of SF3 requiring Cwc22p (Yeh et al. 2010). Prp2p activity results in high-affinity binding sites for Cwc25p and Yju2p, two factors required specifically for $5^{\prime}$ splice site cleavage (Liu et al. 2007b; Chiu et al. 2009; Ohrt et al. 2012), and low-affinity binding sites for the second-step factors Prp16p, Slu7p, and Prp18p-factors required for docking of the $3^{\prime}$ splice site to the active site (Ohrt et al. 2013). Cwc25p, like the SF3b subcomplex, binds the pre-mRNA at or near the branch site (Gozani et al. 1996, 1998; Query et al. 1996; Will et al. 2001; McPheeters

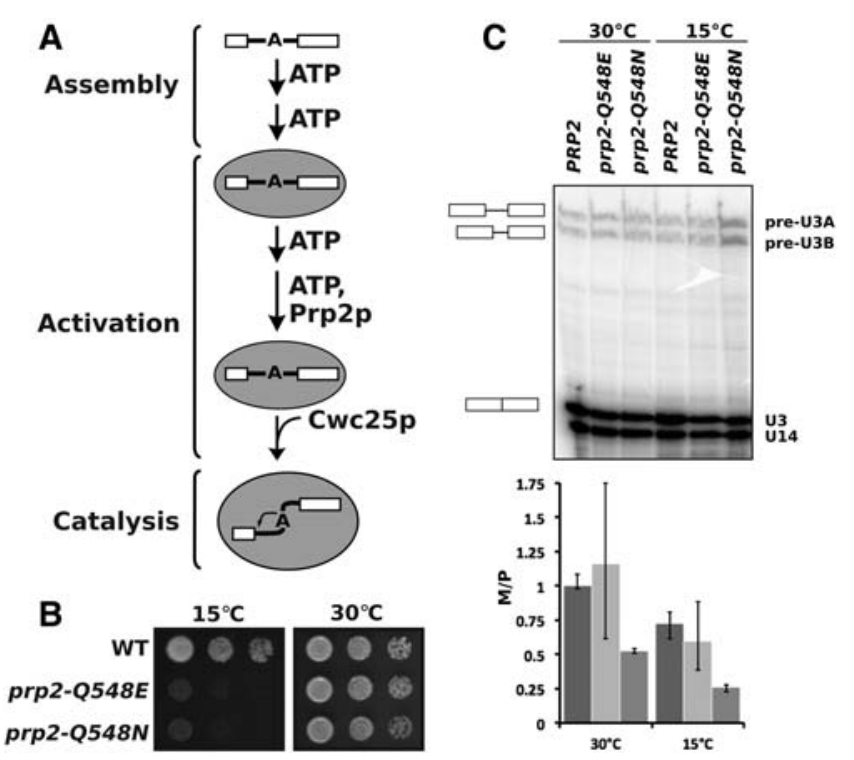

FIGURE 1. Mutations in motif VI of PRP2 lead to cold-sensitive growth and splicing. (A) Diagram of the linear pathway of spliceosome assembly, spliceosome activation, and the first step in catalysis. After Prp2p promotes an RNA rearrangement in the catalytic core, Cwc25p binds the spliceosome, promoting $5^{\prime}$ splice site cleavage. (B) Mutations in PRP2 lead to cold-sensitive growth. Serial dilutions of wild-type (WT) PRP2, prp2-Q548E, and prp2-Q548N were grown on rich media at the permissive temperature $\left(30^{\circ} \mathrm{C}, 2 \mathrm{~d}\right)$ or the restrictive temperature $\left(15^{\circ} \mathrm{C}, 13 \mathrm{~d}\right) .(C)$ The mutant prp2-Q548N compromises splicing. Strains carrying the indicated $P R P 2$ variant were grown at $30^{\circ} \mathrm{C}$ or shifted to $15^{\circ} \mathrm{C}$ and then harvested for whole-cell RNA, which was analyzed for splicing of pre-U3 snoRNA by primer extension. The quantitation below shows the splicing efficiency calculated as $M / P$, where $M$ is the mature $\mathrm{U} 3$ snoRNA and $P$ is the sum of pre-U3A and pre-U3B. The values were normalized to the splicing efficiency in $P R P 2$ at $30^{\circ} \mathrm{C}$. Each bar shows the mean of three replicates, and the error bars show the range of replicates. U14 snoRNA was probed as an internal control. Growth and splicing phenotypes were tested in parental strain yJPS1393, after transformation and shuffle with PRP2 variants and wild-type U2 and U6.

and Muhlenkamp 2003; Chiu et al. 2009; Tseng et al. 2010; Liu and Cheng 2012). Thus, it has been proposed that Prp2p destabilizes SF3 from the pre-mRNA so that Cwc25p can bind and promote catalysis (Lardelli et al. 2010; Yeh et al. 2010), perhaps by positioning the branch-site adenosine for attack at the $5^{\prime}$ splice site. While our understanding of Prp2p-mediated protein dynamics has advanced, little is known about RNA dynamics at this final ATP-dependent stage of spliceosome assembly and activation.

To investigate the role of Prp2p in promoting RNA dynamics, we took a genetic approach used previously to successfully identify functional targets of other DExD/H-box ATPases (Madhani and Guthrie 1994a; Staley and Guthrie 1999; Kistler and Guthrie 2001; Perriman et al. 2003; Schneider et al. 2004; Hilliker et al. 2007; Perriman and Ares 2007; Xu and Query 2007; Mefford and Staley 2009). We generated a cold-sensitive allele of PRP2 and screened for mutations in snRNAs, in addition to proteins, that suppressed the coldsensitive growth defect. We found that the prp2 mutation 
was suppressed not only by mutations in the SF3a-, RES-, and NTC-related complexes, but also in U2/U6 helix I and in U6 residues implicated in a putative catalytic triplex (Toor et al. 2008), providing the first evidence that Prp2p destabilizes snRNA structure, directly or indirectly. Conversely, we found that the cold-sensitive allele of prp2 suppressed dominantnegative and lethal phenotypes of mutations in U2/U6 helix Ia, implicating a role for Prp2p in the fidelity of spliceosome activation. Our data provide evidence that the snRNAs assume a conformation with catalytic features at the Prp2p stage and that this DExD/H-box ATPase promotes activation by proofreading and destabilizing the catalytic core of the spliceosome.

\section{RESULTS}

\section{Mutations in motif VI of Prp2p compromise growth and splicing in the cold}

In our molecular genetic strategy to investigate the role of Prp2p in spliceosome activation, we reasoned that alleles of PRP2 that were cold-sensitive would fail to destabilize the pre-catalytic conformation and thereby prevent the spliceosome from rearranging into the catalytic conformation. Furthermore, mutations in proteins or snRNAs that suppressed a cold-sensitive PRP2 allele would reveal the configuration and dynamics of the spliceosome at this stage. Of 18 alleles that we screened on the basis of cold sensitivity in other spliceosomal DEAH-box ATPases, we found two alleles, prp2-Q548E and prp2-Q548N, that were cold-sensitive (Fig. 1B). The prp2-Q548N mutation compromised splicing of an endogenous transcript, U3 snoRNA, as revealed by primer extension analysis (Fig. 1C). Because the mutations change a residue within the DExD/H-box motif VI, they likely compromise the catalytic functions of Prp2p in ATP binding and/or hydrolysis (Roy et al. 1995; Silverman et al. 2004; Linder and Jankowsky 2011).

\section{PRP2 mutations are suppressed by mutations in the SF3 and RES complexes}

If a role of Prp2p is to destabilize interactions between the spliceosome and the SF3 and RES complexes as well as the NTCrelated proteins Cwc24p and Cwc27p (Warkocki et al. 2009; Lardelli et al. 2010; Ohrt et al. 2012), then mutations in these factors that weaken these interactions should suppress the prp2 mutants. Thus, to test for a role in destabilizing the SF3 complex, we asked whether the cold-sensitive phenotypes of prp2 mutants could be suppressed by the prp9-1 mutation, a temperature-sensitive allele of the gene encoding the SF3a component Prp9p (Legrain and Choulika 1990). This allele disrupts a salt bridge within Prp9p (Lin and Xu 2012) and compromises binding of the U2 snRNP to pre-mRNA (Arenas and Abelson 1993; Ruby et al. 1993). Significantly, the cold-sensitive prp2 mutants were both suppressed by the

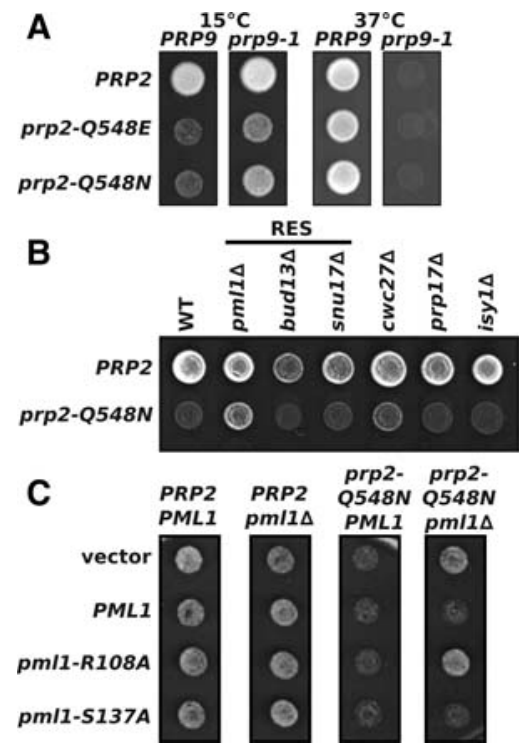

FIGURE 2. Prp2p destabilizes SF3, RES, and NTC-related proteins in vivo. (A) The prp9-1 mutation (Legrain and Choulika 1990) suppresses the cold-sensitive defect of prp2-Q548N. The double deletion strain prp2 2 prp9 $9 \Delta$ carrying plasmids encoding PRP9 or prp9-1 and PRP2, prp2-Q548E, or prp2-Q548N was spotted onto rich media and grown for $2 \mathrm{~d}$ at $37^{\circ} \mathrm{C}$ or for $14 \mathrm{~d}$ at $15^{\circ} \mathrm{C}$. Images were from the same plate but cropped and aligned for clarity. (B) Deletion of PML1, encoding an RES complex component, and deletion of the NTC-related gene CWC27 suppress the prp2-Q548N mutant. Strains deleted for PRP2 and the indicated genes and carrying a plasmid encoding $P R P 2$ or prp2-Q548N were spotted onto rich media and grown for $6 \mathrm{~d}$ at $15^{\circ} \mathrm{C}$. The components of the RES complex are indicated. The contrast for the entire image was adjusted for clarity. $(C)$ A mutation in the FHA motif of PML1 expected to compromise phosphothreonine recognition (Brooks et al. 2009; Trowitzsch et al. 2009) suppresses prp2-Q548N. The wild-type $P M L 1$ or mutant pml1 $\triangle$ strains carrying a plasmid encoding PRP2 or prp2-Q548N and a plasmid encoding PML1, pml1-R108A, pml1-S137A, or an empty parent plasmid (pRS313) were grown for 10 $\mathrm{d}$ at $15^{\circ} \mathrm{C}$ on media lacking histidine to maintain the pRS313 plasmids. All spots were grown on the same plate, but cropped and grouped together for clarity.

prp9-1 mutation (Fig. 2A). This result provides evidence in vivo that Prp2p destabilizes the SF3 complex, weakening interactions between the U2 snRNP and the pre-mRNA.

To test for a role for Prp2p in rearranging the RES complex (Dziembowski et al. 2004), composed of Pmllp, Bud13p, and Snu17p, or in rearranging the NTC-related protein Cwc27p, we asked whether the cold-sensitive phenotype of a prp2 mutant could be suppressed by deletion of any of the encoding genes, as compared with deletion of control genes, PRP17 and ISY1; Prp17p and Isylp bind the spliceosome before the Prp2p-dependent step (Fabrizio et al. 2009; Lardelli et al. 2010), but Prp17p functions afterward (Jones et al. 1995), and the ISY1 deletion suppresses a prp16 mutation that compromises an ATP-dependent step in splicing that follows Prp2p action (Villa and Guthrie 2005). We found that the prp2-Q548N mutant was suppressed specifically by deletion of PML1 or CWC27 (Fig. 2B). Interestingly, Pml1p has an FHA domain; such domains can bind phosphothreonine 
peptides (Brooks et al. 2009; Trowitzsch et al. 2009), and in the crystal structure of Pml1p, the highly conserved residue $\mathrm{R} 108$, in the putative phosphopeptide-binding core, binds sulfate, strongly implicating this residue in binding phosphate as in other FHA family members (Brooks et al. 2009; Trowitzsch et al. 2009). Strikingly, mutation of this residue, but not another, was sufficient to suppress the prp2 mutant; whereas wild-type PML1 complemented the deletion of PML1 and abolished suppression of prp2, pml1-R108A did not (Fig. 2C); an equivalent mutation in the FHA domain of Rad53 decreased binding of phosphothreonine peptides 10-fold (Durocher et al. 1999). Thus, the suppression of prp2 by pml1-R108A suggests a role for recognition of a phosphothreonine at this stage of splicing (cf. Brooks et al. 2009) and destabilization of this interaction by Prp2p. Overall, these data provide evidence in vivo that Prp2p destabilizes the SF3 and RES complexes and Cwc27p.

\section{Prp2p destabilizes U2/U6 helix la}

To test whether Prp2p also rearranges RNA, we asked whether mutations in snRNAs suppressed prp2-Q548N. We screened mutations in residues involved in several structures, including U2/U6 helix I (Madhani and Guthrie 1992; Sun and Manley 1995; Mefford and Staley 2009), the extended U6 ISL (Sun and Manley 1995; Sashital et al. 2004), U2 stem I (Wu and Manley 1992), U2 stem II (Ares and Igel 1990; Zavanelli et al. 1994), and the U2 branch point stem-loop (BSL) (Perriman and Ares 2010). With only one exception (see below), we did not observe suppression of prp2-Q548N by any mutations in the U6 ISL, U2 stem I, U2 stem II, or the U2 BSL. In contrast, we observed broad and dramatic suppression in residues that participate in U2/U6 helix I. The prp2Q548N mutant was suppressed by mutations in seven of the eight nucleotides (nt) of helix Ia (Fig. 3A-E), the structure implicated in juxtaposing the branch site and $5^{\prime}$ splice site; mutations at the remaining residue, U2-G26, are lethal in a wild-type strain. Furthermore, a compensatory analysis of suppressors that would disrupt the U2/U6-C29/G55 base pair revealed that double mutations that restored WatsonCrick base-pairing specifically abolished suppression, providing evidence that this base pair is formed before Prp2p acts and is destabilized when Prp2p acts (Fig. 3E; Supplemental Fig. S1A). For example, the point mutations U2-C29A and U6-G55U each suppressed prp2-Q548N, but the compensatory mutation U2/U6-C29A/G55U abolished suppression; in contrast, noncompensatory mutations, such as U2/U6C29A/G55A, did not abolish suppression. While a simple compensatory analysis of the U2/U6 base pair U28/A56 was not sufficient to reveal evidence for base-pairing at this position (Supplemental Fig. S1B), we found serendipitously that in the background of a third aphenotypic mutation (U2$\Psi 44$ C), a compensatory analysis did provide evidence for base-pairing at this position (Fig. 3F). At the U2/U6 base pair A27/U57, the suppression of prp2 by U6-U57A was

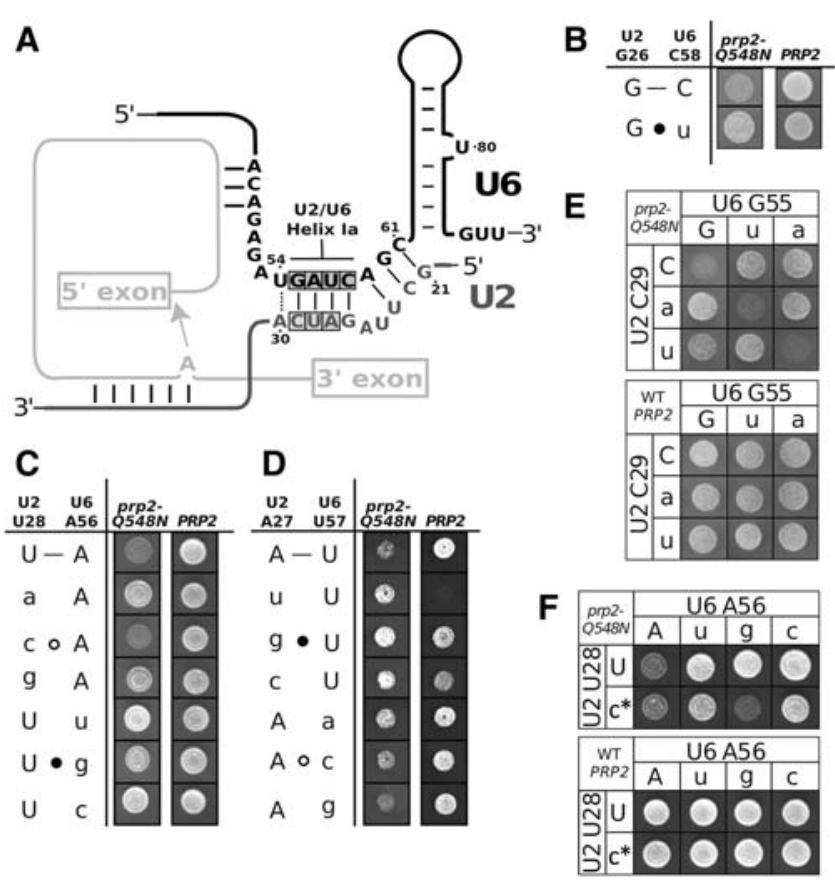

FIGURE 3. Prp2p destabilizes U2/U6 helix Ia. (A) Secondary structural model of U2/U6 helix I showing residues in helix Ia that were tested as boxed letters and residues that suppress prp2-Q548N when mutated as shaded boxes. $(B-F)$ Mutations that disrupt U2/U6 helix Ia suppress prp2-Q548N. $(B-D)$ Point mutations in U2/U6 base pairs $\mathrm{G} 26 / \mathrm{C} 58$ $(B), \mathrm{U} 28 / \mathrm{A} 56(C)$, and A27/U57 (D) illustrate the suppression of prp2-Q548N by mutations that disrupt helix Ia. $(E, F)$ Compensatory analyses at the U2/U6 base pairs C29/G55 (E) and U28/A56 (F) show that suppression is specifically abolished by restoration of base-pairing. In $B-F, P R P 2$ or prp2-Q548N cells containing the indicated U2 and U6 alleles were grown for $10-16 \mathrm{~d}$ at $15^{\circ} \mathrm{C}$. For $B, C, E$, and $F$, cells were grown on rich media. For $D$, in which $\mathrm{U} 2$ dominant phenotypes were assayed, cells were grown on selective media, after transformation with U2 plasmids, to retain both the wild-type and mutant U2 plasmids. Phenotypes were tested in parental strain yJPS1393. $\left(^{*}\right)$ This U2 variant included the mutation U2- $\Psi 44 \mathrm{C}$, which shows no phenotype alone, yielding the double U2 mutation $\mathrm{U} 2-\mathrm{U} 28 \mathrm{C} / \Psi 44 \mathrm{C}$.

also specifically compromised by a compensatory mutation (Supplemental Fig. S1C; Supplemental Note 1). While some prp2 mutant suppressors in U2/U6 helix Ia were not abolished by compensatory mutations, as for some prp16 mutant suppressors in U2/U6 helix Ia (Mefford and Staley 2009), such negative results may reflect, for example, a requirement for the purine-pyrimidine polarity of the base pair; constraints imposed by additional, tertiary interactions; or limitations of the approach resulting from disruption of alternative interactions that function at other stages. Taken together, these data provide evidence that helix Ia forms before Prp2p acts, and the data suggest further that U2/U6 helix Ia is destabilized by $\operatorname{Prp} 2 \mathrm{p}$.

\section{Prp2p destabilizes U2/U6 helix Ib}

Similar to mutations in helix Ia, prp2-Q548N was suppressed by several of the 11 aphenotypic point mutations in helix Ib, a 
A
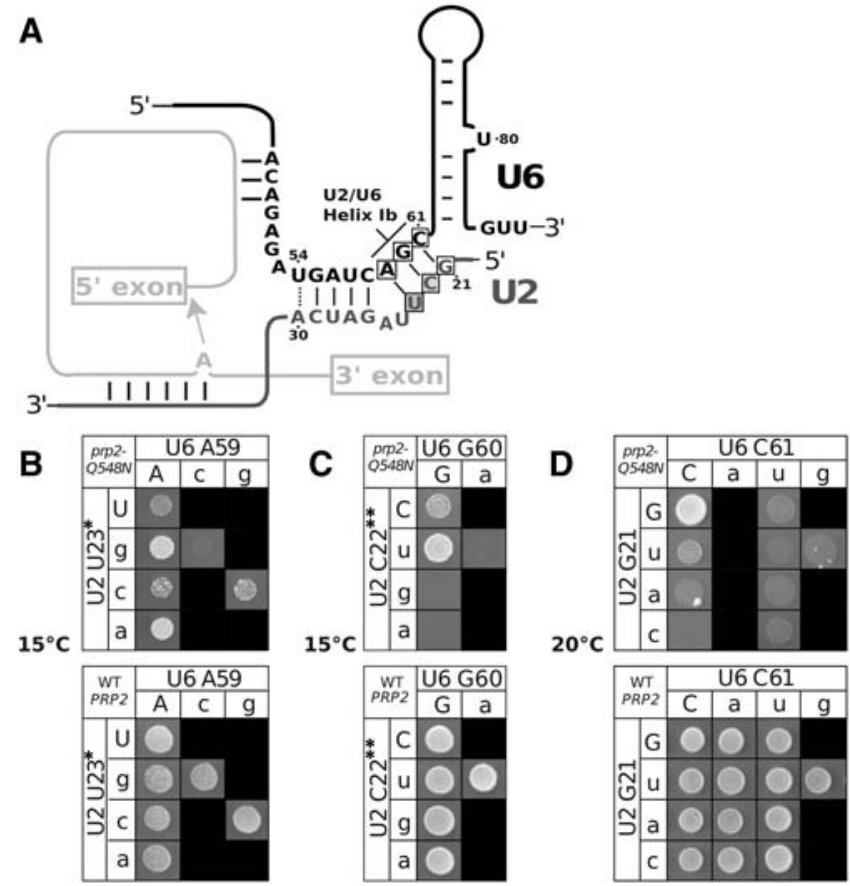

FIGURE 4. Prp2 destabilizes U2/U6 helix Ib. (A) Secondary structural model of U2/U6 helix I showing residues in helix Ib that were tested as boxed letters and residues that suppress $p r p 2-Q 548 N$ when mutated as shaded boxes. $(B, C)$ Mutations in $\mathrm{U} 2 / \mathrm{U} 6$ helix Ib residues suppress prp2-Q548N. PRP2 (bottom) or prp2-Q548N (top) cells containing the indicated $\mathrm{U} 2$ and $\mathrm{U} 6$ alleles were grown on rich media. (B) Compensatory analysis of U2/U6 base pair U23/A59. Cells were grown at $16^{\circ} \mathrm{C}$ for $5 \mathrm{~d}(P R P 2)$ or $10 \mathrm{~d}$ (prp2-Q548N). (C) Compensatory analysis of U2/U6 base pair C22/G60. Cells were grown at $16^{\circ} \mathrm{C}$ for $5 \mathrm{~d}$ (PRP2) and $10 \mathrm{~d}$ (prp2-Q548N). (D) Compensatory analysis of U2/U6 base pair $\mathrm{G} 21 / \mathrm{G} 61$. Cells were grown for $6 \mathrm{~d}$ at $20^{\circ} \mathrm{C}$ to assay for exacerbation of the prp2-Q548N mutant. Phenotypes were tested in parental strain yJPS1393. (*) Secondary mutations at U2-U12 preserve bulge in U2 stem I. (**) Compensatory mutations at U2-G13 preserve Watson-Crick base-pairing in U2 stem I.

component of the structure that acts at the catalytic stage and positions catalytic metals (Hilliker and Staley 2004; Mefford and Staley 2009; Fica et al. 2013). Specifically, prp2-Q548N was suppressed by the three U2 mutations, C22U, U23G, and U23A (Fig. 4A-C). Suppression of prp2-Q548N by two of these mutations, U2-C22U and U2-U23G, was abolished by the U6 compensatory mutations that restored helix Ib (Fig. 4B,C), but not by compensatory mutations in the competing structure U2 stem I or the extended U6 ISL, and point mutations specific to these alternative base-pairing partners did not suppress prp2-Q548N on their own, with only one exception (Supplemental Fig. S2). These data provide evidence that helix Ib forms before Prp2p acts and suggest further that Prp2p destabilizes helix Ib.

In contrast with helix Ia mutations, we also found that six point mutations in U2/U6 helix Ib exacerbated the prp2Q548N mutant. For example, in the helix Ib base pair U2/ U6-G21/C61, the base substitutions U6-C61U and U6C61A and all three base substitutions of U2-G21 exacerbated
prp2-Q548N or resulted in synthetic lethality with prp2Q548N (Fig. 4D). Although in the one testable case, restoring base-pairing in helix Ib with a compensatory mutation did not rescue growth, compensatory mutations in alternative structures, including U2 stem I or the extended U6 intramolecular stem-loop (ISL), also failed to improve growth, and point mutations specific to these alternative base-pairing partners did not exacerbate prp2-Q548N on their own, with the exception of only one residue (Supplemental Fig. S2). Taken together, our observations are consistent with the exacerbation of prp2 deriving from destabilization of helix Ib and suggest that Prp $2 \mathrm{p}$ promotes a conformation particularly sensitive to base-pair identity in helix Ib. Indeed, repair of helix Ib with compensatory U6 mutations that restored base-pairing with U2-C22U or U23G not only abolished suppression of prp2-Q548N by these U2 mutations but also exacerbated the cold-sensitive phenotype of the prp2 mutant (Fig. 4B,C). Overall, these data provide evidence that Prp2p destabilizes helix Ib and does so to promote a conformation of helix Ib within a new context that promotes catalysis (see Discussion).

\section{Prp2p destabilizes putative base triple interactions}

Because our data suggested that the catalytic core components U2/U6 helix Ia and helix Ib are both formed before Prp2p acts, we hypothesized that additional features of the catalytic core have also formed by this stage-in particular, a putative catalytic triplex that would result from base triple interactions between U2/U6 helix Ib and residues in the highly conserved U6 ACAGAGA and the U6 ISL (Fig. 5A). This putative triplex is predicted from a crystal structure of a self-splicing group II intron, in which the triplex plays a key role in positioning catalytic divalent metal ions (Fig. 5B; Toor et al. 2008). To test our hypothesis, we asked whether prp2-Q548N could be suppressed by mutations in the U6 residues predicted to interact with U2/U6 helix Ib: A53, G52, and U80. We also asked whether the prp2-Q548N mutant could be suppressed by mutations in U6-U54, since U54 could potentially extend the triplex through an interaction with the U2/U6 helix Ia pair G26/ C58, as suggested by covariation among different species (Madhani and Guthrie 1992).

Consistent with base triple interactions already being formed at the Prp2p stage, prp2-Q548N was strongly suppressed by mutations in three of the four putative U6 base triple partners: the mutations U6-A53U, U6-A53G, U6-U80C, and all three mutations at U6-U54 (Fig. 5A,C,E,F; cf. 5D). In total, six of nine testable mutations suppressed prp2-Q548N. Consistent with the formation of an extended triplex, the suppression by mutations in U6-U54 was not abolished by either compensatory mutations in $\mathrm{U} 2$ that would restore a potential lengthening of U2/U6 helix Ia (Supplemental Fig. $\mathrm{S} 3 \mathrm{~A}, \mathrm{~B})$ or by compensatory mutations in the U6 central stem (Supplemental Fig. S3C,D). Furthermore, at the putative triple partner, U2/U6 base pair G26/C58, two allele 

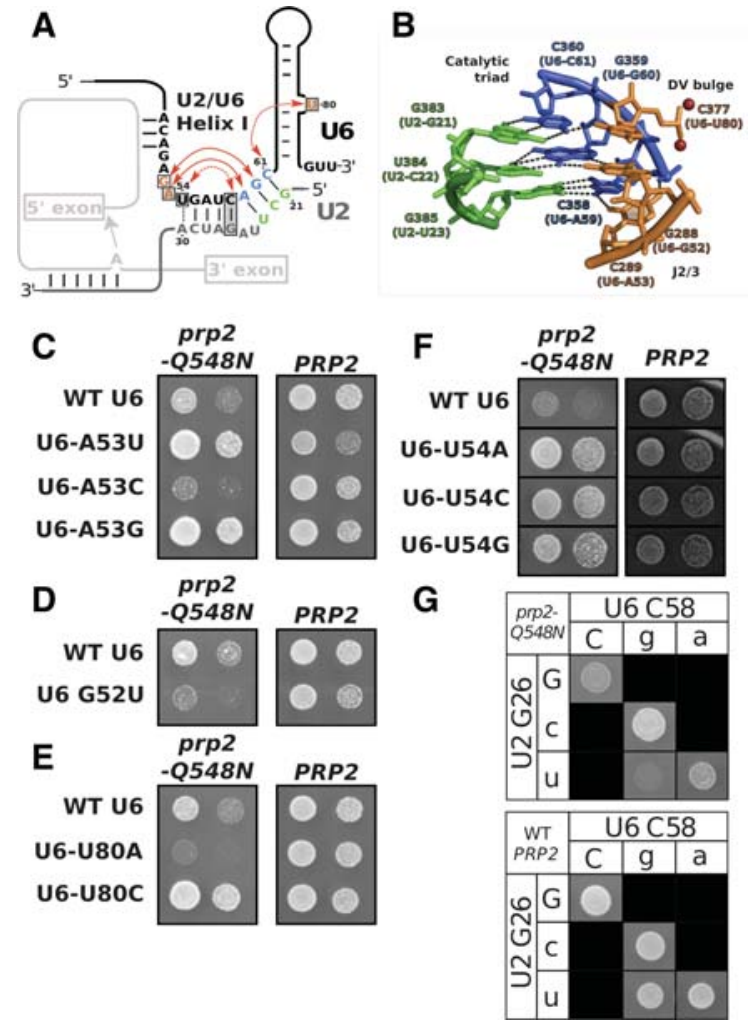

FIGURE 5. Prp2p destabilizes putative base triple interactions. (A) Diagram of predicted base triple interactions in the catalytic core of the spliceosome. (Solid red arrows) Base triple interactions predicted by the group II intron structure (Toor et al. 2008); (dashed red arrow) a base triple implicated by covariation (Madhani and Guthrie 1992). (Boxed residues) Bases that were tested for genetic interactions with prp2-Q548N; (shaded boxes) positions or base pairs that showed suppression. Within the putative triplex, helix $\mathrm{Ib}$ residues involved in Watson-Crick base-pairing between U2 (green) and U6 (blue) are shown, as are U6 residues of the ACAGAGA sequence and U80 (orange) proposed to interact with helix Ib. (B) Base triple interactions of the catalytic triplex observed in the crystal structure of the Oceanobacillus iheyensis group II intron (Toor et al. 2008). The color coding of the equivalent triplex residues is the same as in panel $A$. The two putative catalytic metals are shown as spheres. $(C-F)$ Mutations in the third base of three predicted base triples suppress prp2-Q548N. Cells were grown on rich media at $15^{\circ} \mathrm{C}$ for $5 \mathrm{~d}(P R P 2)$ or $12 \mathrm{~d}$ (prp2-Q548N). $(G)$ At the U2/U6 base pair G26/C58, non-wild-type, Watson-Crick base-pair combinations suppress prp2-Q548N. Cells were grown on rich media for $10 \mathrm{~d}$ at $15^{\circ} \mathrm{C}$. (Black boxes) Allele combinations that were not included in the analysis because they have previously been reported as lethal (Mefford and Staley 2009). In each panel, all strains were grown on the same plate; images were cropped and grouped together for clarity. Phenotypes were tested in parental strain yJPS1393.

combinations that maintained base-pairing but altered basepair identity also suppressed prp2-Q548N (Fig. 5G). These data are not only consistent with the presence of the putative base triple interactions at the Prp2p stage, but also suggest that Prp2p destabilizes tertiary RNA interactions, in addition to base-pairing and protein-RNA interactions (Warkocki et al. 2009; Lardelli et al. 2010). Still, proof that the putative triples form will require further genetic and biochemical investigations.

\section{Prp2p proofreads catalytic core formation}

Unexpectedly, we not only observed that snRNA mutations suppressed prp2-Q548N but also conversely that a prp2 mutation suppressed select snRNA mutations-that prp2 and snRNA mutations mutually suppressed one another. Specifically, we discovered that prp2-Q548N rescued the dominant-negative phenotype of two mutations, U2-A27U and -A27C (Fig. 3D). While this rescue could have formally indicated that the prp2 mutation somehow prevented incorporation of $\mathrm{U} 2$ harboring these mutations into the spliceosome, thereby favoring incorporation of wild-type U2, the same U2 mutations suppressed the prp2 mutation, arguing against this possibility and for a role for the prp2 mutation in suppression by enabling the dominant-negative U2 mutations to function within the spliceosome. Confirming this

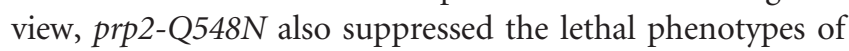
two U2 mutations in helix Ia: A27U and A27G (Fig. 6). These surprising observations indicate that the dominantnegative and lethal phenotypes of these mutations depend on the wild-type activity of Prp2p. That is, wild-type Prp2p activity is required to ensure that suboptimal spliceosomes compromised by these U2/U6 helix Ia mutations do not function. While a final test of the model will require biochemical tests, these data implicate Prp2p for the first time as a spliceosomal DExD/H-box fidelity factor (Semlow and Staley 2012) and one that proofreads formation of the catalytic core.

\section{DISCUSSION}

The role of Prp2p in spliceosome activation is essential to premRNA splicing (Kim and Lin 1993, 1996). Several studies have implicated Prp2p in destabilizing protein complexes (Bessonov et al. 2008; Fabrizio et al. 2009; Warkocki et al. 2009; Lardelli et al. 2010; Ohrt et al. 2012), but to date, there has been little indication that Prp2p destabilizes RNA, despite its membership in the DExD/H-box family of ATPases. Furthermore, while features of the spliceosome's catalytic RNA core have been defined, such as U2/U6 helix I (Madhani and Guthrie 1992; Sun and Manley 1995; Hilliker

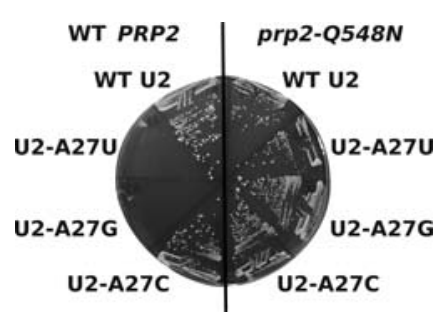

FIGURE 6. Prp2p proofreads the catalytic core. The prp2-Q548N mutant rescues the lethality of $\mathrm{U} 2-\mathrm{A} 27 \mathrm{U}$ and $\mathrm{U} 2-\mathrm{A} 27 \mathrm{G}$. To assay recessive U2 phenotypes, the indicated strains carrying a copy of both wild-type U2 (on a URA3-marked plasmid) and the indicated U2 variant were streaked onto 5-FOA to counterselect against cells containing the wild-type U2 plasmid. Cells were grown for $4 \mathrm{~d}$ at $30^{\circ} \mathrm{C}$. Phenotypes were tested in parental strain yJPS1393. 
and Staley 2004; Mefford and Staley 2009), it has remained unclear when these features form during spliceosome activation. Here, using a cold-sensitive PRP2 mutation as a tool to study the activation stage, we have provided evidence that key features of the catalytic core, including U2/U6 helix I and putative, catalytic base triples, are already formed in vivo at the Prp2p stage (Figs. 3-5; Supplemental Fig. S1). Since these features are not yet competent to promote catalysis without the role of Prp2p in the final ATP-dependent step of spliceosome activation, we infer that formation of U2/U6 helix I and the putative base triples is not sufficient to catalyze splicing. Indeed, providing the first evidence indicating that Prp2p destabilizes RNA structure, our data imply that Prp2p destabilizes the catalytic RNA core, directly or indirectly (Figs. 3-5). Strikingly, a prp2 mutation rescues lethal helix Ia mutations, establishing evidence that Prp2p not only destabilizes the catalytic core but also proofreads this essential RNA element (Fig. 6).

\section{A nascent catalytic core is formed before the final stages of spliceosome activation}

U2/U6 helix Ia is thought to juxtapose the branch site and the $5^{\prime}$ splice site (Madhani and Guthrie 1992; Sun and Manley 1995; Mefford and Staley 2009). Consistent with recent chemical probing data (Anokhina et al. 2013), our data indicate that U2/U6 helix Ia is already formed before Prp2p promotes the final stages of spliceosome activation (Fig. 3). Consistent with this conclusion, recent single-molecule FRET studies indicate that the branch site and $5^{\prime}$ splice site move closer to one another at or near the Prp2p stage (Crawford et al. 2013; Krishnan et al. 2013). Since helix Ia is already formed at the Prp2p stage and the spliceosome is not yet competent to undergo the chemistry of splicing, our data imply that helix Ia-mediated juxtaposition of the $5^{\prime}$ splice site and branch site is not sufficient to promote the first step of splicing. Other features of the catalytic core must be limiting for the complete activation of the spliceosome.

We also provide evidence that $\mathrm{U} 2 / \mathrm{U} 6$ helix Ib is already formed before the final stages of activation (Fig. 4), and our data are consistent with formation of putative base triple interactions (Toor et al. 2008) by the Prp2p stage (Fig. 5), although further studies will be required to unequivocally establish formation of the triples. Residues that would engage in the triples include the AGC triad of helix Ib and the bulged U80 of the U6 ISL. These residues have recently been shown to coordinate metal ions that mediate the catalysis of both steps of pre-mRNA splicing (Fica et al. 2013). Since our data imply that helix Ib, and potentially the catalytic triplex, is already formed at the Prp2p stage, binding of metals by helix Ib may not be limiting at the final step of spliceosome activation, similar to helix Ia-mediated substrate juxtaposition. Thus, our findings support a view in which the final rearrangements in spliceosome activation involve fine-tuning of substrate conformation.

\section{Differences in snRNA structure formed at the Prp2p stage and the catalytic stage}

Mutations in U2/U6 helix I suppress not only a cold-sensitive mutation in PRP2 but also a cold-sensitive mutation in PRP16 (Madhani and Guthrie 1992, 1994a; Mefford and Staley 2009), a DExD/H-box ATPase that is required just after $5^{\prime}$ splice site cleavage (Schwer and Guthrie 1992). This parallel establishes that helix I is formed and destabilized at both of these stages. Still, despite this parallel, more subtle differences in the genetic interactions between snRNA mutations and prp2 and prp16 mutants point to conformational differences between these stages that result from Prp2p action. First, two mutations in helix Ia, U6-U57A and U6-U57C, have opposite effects on the phenotype of a prp16 mutation, leading to the interpretation that U57A is relatively destabilizing to the $5^{\prime}$ splice site conformation while U57C is stabilizing; further genetics indicate that these mutations act inversely at the second step of splicing: U57A is relatively stabilizing for the exon ligation conformation, while U57C is relatively destabilizing (McPheeters 1996; Query and Konarska 2004; Konarska et al. 2006; Liu et al. 2007a; Mefford and Staley 2009; Query and Konarska 2012). In contrast, these U6-U57 alleles do not show this dichotomy of genetic interactions with prp2; prp2-Q548N is modestly suppressed by U6-U57A, but it is not exacerbated by U6-U57C (Fig. 3D). Second, while some mutations in the U2/U6 helix Ib pair C21-G61 suppress prp16 (Mefford and Staley 2009), no mutations in this pair suppress prp2-indeed, all exacerbate (Fig. 4D). Third, while only one mutation in U6-U54 suppresses prp16, all base substitutions in U6-U54 suppress prp2 (cf. Fig. 5D and Mefford and Staley 2009), perhaps by destabilizing a putative base triple between U6-U54 and U2/U6-G26/C58, suggested by covariation (Madhani and Guthrie 1992). In this case, the genetic differences may reflect that the possible base triple is formed at the Prp2p stage but not at the Prp16p stage. Finally, while deletion of the gene encoding the NTC protein Isylp suppresses the cold-sensitive defect of prp16-302 (Villa and Guthrie 2005), deletion of this gene does not suppress prp2-Q548N (Fig. 2B). Together, these genetic differences indicate that unique features of the catalytically active core are not yet formed at the Prp $2 p$ stage and suggest a role for Prp2p in consolidating interactions around the catalytic core during the final stage of spliceosome activation.

\section{The role for Prp2p in destabilizing snRNA structure in the catalytic core}

Complementing the already established role that Prp2p plays in destabilizing proteins (Bessonov et al. 2008; Fabrizio et al. 2009; Warkocki et al. 2009; Lardelli et al. 2010; Ohrt et al. 2012), our investigation has provided evidence that Prp2p destabilizes U2/U6 helix I, in addition to putative base triples (Figs. 3-5). For several other DExD/H-box ATPases, it is clear from molecular genetic studies that destabilization of a 
structure equates with disruption of the structure because the ATPases drive the formation of alternative, mutually exclusive structures (Fleckner et al. 1997; Staley and Guthrie 1999; Perriman et al. 2003; Hilliker et al. 2007; Perriman and Ares 2007, 2010). If by destabilizing U2/U6 helix I, Prp2p fully disrupts the catalytic core, directly or indirectly, then the catalytic core would need to be re-stabilized for catalysis. Establishing precedence for such a toggling rearrangement, Prp16p destabilizes the catalytic core transiently: After Prp16p destabilizes the $5^{\prime}$ splice site cleavage conformation, promoting formation of an intermediate state, the spliceosome re-stabilizes the catalytic core for exon ligation (Mefford and Staley 2009). This transient disruption of the catalytic core is thought to allow repositioning of the reactants for exon ligation (Schwer and Guthrie 1992). Prp2p could similarly destabilize the catalytic core to allow positioning of the substrate for $5^{\prime}$ splice site cleavage, a function that could couple with the role for Prp2p in destabilizing SF3 to exposes the branch site adenosine for attack (Warkocki et al. 2009; Lardelli et al. 2010), especially since helix I is immediately adjacent to the U2/branch site helix (Fig. 3A). Together, genetic investigations of helix I at the Prp2p and catalytic stages suggest the intriguing notion that the catalytic core is inherently stable, forming in ATP-independent steps, and that $\mathrm{DExD} / \mathrm{H}$ box ATPases function in part to counteract this stabilizing force to enable rearrangements of the substrate.

In addition to destabilizing SF3 to promote the binding and stabilization of Cwc25p and Yju2p (Liu et al. 2007b; Chiu et al. 2009; Ohrt et al. 2012), Prp2p may function, through reconfiguration of the nascent catalytic core, to enable binding of proteins to the catalytic core to induce a catalytically active configuration. Recent biochemical experiments indicate that Cwc2p, a protein with an RNA recognition motif (RRM), protects helix I from modification before Prp2p acts (McGrail et al. 2009; Rasche et al. 2012; Schmitzová et al. 2012). Although this protection could be indirect, destabilization of helix I may consequently remodel interactions between Cwc2p and the catalytic core. Indeed, Cwc2p crosslinks to the U6 ISL, and this cross-linking changes as a consequence of Prp2p function in both yeast and mammals (Rasche et al. 2012). In addition to Cwc2p, Prp8p is thought to function as a scaffold for the catalytic RNA core (Galej et al. 2013), as implicated by cross-linking (Turner et al. 2006), genetics (Query and Konarska 2004), and crystallography (Pena et al. 2008; Ritchie et al. 2008; Yang et al. 2008; Galej et al. 2013). Thus, by destabilizing U2/U6 helix I, Prp2p may also promote this scaffolding function of these proteins.

\section{The role of Prp2p in destabilizing proteins}

Our results show that prp9-1, a temperature-sensitive mutation in the SF3a protein Prp9p (Legrain and Choulika 1990), suppresses prp2 (Fig. 2A), consistent with the proteomic result that SF3 is destabilized by Prp2p (Warkocki et al. 2009; Lardelli et al. 2010). The human SF3 components
SAP155p (also known as SF3b1p or SF3b155p), SAP145p (also known as SF3b2p, Cus1p, or SF3b145p), and p14 cross-link near the branch site (Gozani et al. 1996, 1998; Query et al. 1996; Will et al. 2001), as does the yeast SF3b155p homolog Hsh155p (McPheeters and Muhlenkamp 2003; Liu and Cheng 2012). Thus, it has been hypothesized that destabilization of SF3 by Prp2p could remove steric constraints and allow Cwc25p binding to enable positioning of the branch site for $5^{\prime}$ splice site cleavage (Chiu et al. 2009; Warkocki et al. 2009; Lardelli et al. 2010; Tseng et al. 2010; Yeh et al. 2010). Since Prp2p cross-links to the pre-mRNA just downstream from the branch site and this region is required for Prp2p function (Teigelkamp et al. 1994; Liu and Cheng 2012), Prp2p has been proposed to destabilize directly interactions between the pre-mRNA and SF3 near the branch site of the pre-mRNA (Warkocki et al. 2009; Lardelli et al. 2010). The suppression of prp2 by prp9-1 (Fig. 2A) is consistent with Prp2p-mediated repositioning of the branch site, because the prp9-1 mutation destabilizes the interaction between the branch site and the U2 snRNP (Ruby et al. 1993). Furthermore, these phenotypes of prp9-1 together indicate that alternative interactions must substitute for SF3 in stabilizing the U2/branch site interaction, which is required at the catalytic stage of splicing (Smith et al. 2009).

Interestingly, our data also implicate a role for the RES complex in phosphothreonine recognition at, and likely before, the Prp2p stage. Specifically, a prp2 mutant is robustly suppressed by a point mutation predicted from homology (Durocher et al. 1999) and crystallography (Brooks et al. 2009; Trowitzsch et al. 2009) to directly disrupt phosphothreonine recognition by the FHA domain of Pmllp (Fig. 2C). This observation implies that phosphothreonine recognition by Pmllp stabilizes an interaction that Prp2p destabilizes. A number of splicing factors are phosphorylated, and two are phosphorylated in a dynamic manner (Wang et al. 1998; Agafonov et al. 2011). However, few phosphorylations are understood in terms of their importance or their recognition. Several SF3 factors are phosphorylated (Wang et al. 1998; Agafonov et al. 2011), suggesting the possibility that Pmllp binds to one of these phosphorylated residues to stabilize SF3 binding to the spliceosome. Future experiments will be required to identify the putative target of Pmllp.

\section{A role for Prp2p in proofreading the catalytic core}

It has been predicted that all spliceosomal DExD/H-box ATPases act as proofreading factors, in addition to driving the spliceosome forward along the splicing pathway (Burgess and Guthrie 1993b). However, it is not yet known if this is the case. Extending support for this hypothesis, we show here that Prp2p functions as a fidelity factor, in addition to five of the other seven DExD/H-box ATPases (Burgess and Guthrie 1993a; Mayas et al. 2006, 2010; Xu and Query 2007; Koodathingal et al. 2010; Perriman and Ares 2010; Yang et al. 2013). A role for Prp $2 p$ in fidelity was revealed through the 
striking observation that $\operatorname{prp} 2-\mathrm{Q} 548 \mathrm{~N}$ rescues the dominantnegative or lethal phenotypes of mutations in U2-A27 (Figs. $3 \mathrm{D}, 6$ ). Mutation of U2-A27 could in principle compromise growth by destabilizing any of various structures, including U2 stem I, the U2 BSL, or U2/U6 helix Ia, but given our evidence that U2/U6 helix Ia is formed before Prp2p acts and that Prp2p destabilizes helix Ia, we infer that the defect of U2-A27 mutations that is suppressed by prp2 results from disruption of base-pairing in U2/U6 helix Ia. While the mechanism of this proofreading could be indirect, such as by premature destabilization of SF3, the function of this proofreading must be tied, minimally, to the role of U2-A27. Thus, our data provide the first evidence that a DExD/H-box ATPase proofreads formation of an snRNA/snRNA interaction within the spliceosome. In a wild-type spliceosome, we imagine that formation of the catalytic core is not a straightforward RNA folding problem and that folding "errors" occur that must be corrected in a manner parallel and mechanistically equivalent to the correction of substrate-binding "errors" (see below). Given the proximity of helix Ia to the U6/5' splice site interaction and the U2/branch site interaction, a concomitant role for Prp $2 p$ in proofreading these interactions is an intriguing possibility. While preliminary tests have not revealed such a role, further experiments are required to test this possibility rigorously.

The prevailing model for how spliceosomal DExD/H-box ATPases act as fidelity factors (for review, see Semlow and Staley 2012) specifies that $\mathrm{DExD} / \mathrm{H}$-box ATPases can compete with a productive step in splicing, such as U2 snRNP binding (Xu and Query 2007; Perriman and Ares 2010), 5' splice site cleavage (Burgess and Guthrie 1993a; Koodathingal et al. 2010), or exon ligation (Mayas et al. 2006), and thereby establish a rejection branch. By this kinetic proofreading model, Prp2p can compete (Fig. 7, step i), through premature destabilization of U2/U6 helix I and SF3, with a currently undefined step (see below) in the productive pathway of spliceosome activation (ii). If the spliceosome is suboptimal, for example, by not fully forming helix Ia or interactions with helix Ia, then Prp2p would act before the productive step (ii) to reject the suboptimal spliceosome (i); if the spliceosome is optimal, for example, by fully forming helix Ia, the spliceosomes would proceed along the productive pathway (ii), and Prp $2 p$ would act after the productive step (ii) to activate the spliceosome (iii).

In kinetic proofreading, the sorting of suboptimal and optimal spliceosomes between rejection and productive pathways can be achieved by one of two nonmutually exclusive mechanisms (Semlow and Staley 2012). First, these ATPases could generally enforce a time limit on the productive step in splicing. In support of this possibility, Prp16p has been shown to preferentially reject spliceosomes that catalyze $5^{\prime}$ splice site cleavage slowly (Koodathingal et al. 2010; Koodathingal and Staley 2013). Similarly, Prp2p could act as a proofreading timer by limiting the amount of time available for the productive step (ii). If the productive step (ii) does not occur

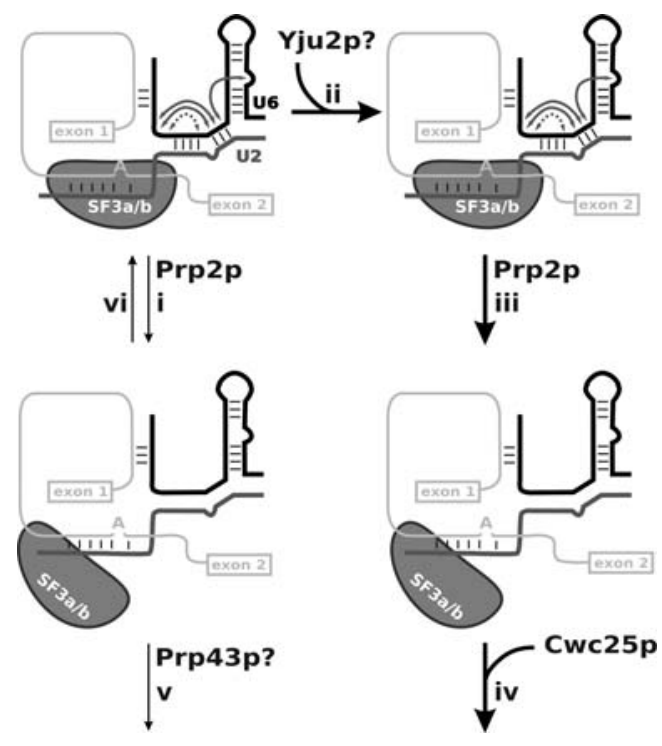

FIGURE 7. Model of the branched pathway for the proofreading activity of Prp2p. In this kinetic proofreading model (Semlow and Staley 2012), Prp2p-dependent rejection (i) competes with a yet undefined transition along the productive pathway of activation (ii) to antagonize activation of a suboptimally configured spliceosome. Prp2p-dependent rejection would yield an intermediate that could either undergo discard by Prp43p (v) (Pandit et al. 2006; Koodathingal et al. 2010; Mayas et al. 2010; Chen et al. 2012) or re-engage the productive pathway (vi). In contrast, an optimally configured spliceosome would proceed preferentially through the undefined stage in activation (ii), after which Prp $2 p$ would promote spliceosome activation (iii). The prevailing model for activation posits that Cwc25p replaces binding of SF3 near the branch site (iv) (Yeh et al. 2010; Ohrt et al. 2012). Our data indicate that, in addition, Prp2p promotes destabilization of snRNA structure in the catalytic core (iii), pictured by the loss of both U2/U6 helix I base-pairing and putative base triples. In the model, Prp2p drives these protein and RNA dynamics in both rejecting suboptimal spliceosomes and in promoting optimal spliceosomes. Thus, the consequence of $\operatorname{Prp} 2 \mathrm{p}$ activity, productive or antagonistic, depends on its timing of action. (Thick arrows) The canonical activation pathway; (gray arrows in the secondary structure diagrams) putative base triple interactions.

in a given window of time, because U2-A27U or helix Ia mispairing, for example, delays the productive step (ii), then Prp2p would reject the spliceosome (i). One attractive candidate for the productive step is Yju2 binding, since Prp2p can function before or after Yju2 binds to the spliceosome (Liu et al. 2007b), just as Prp16p, for example, can function before or after $5^{\prime}$ splice site cleavage (Koodathingal et al. 2010; Tseng et al. 2010). Another attractive candidate is Cwc2p association with the catalytic core, given that Cwc2p protects helix I before Prp2p acts (Rasche et al. 2012); if, for example, a mutation or mispairing in helix I delays Cwc2p binding, Prp2p may act prematurely, rejecting the configuration.

In the second possible mechanism for sorting, the proofreading DExD/H-box ATPase could sense the authenticity of a substrate. In this case, the suboptimal U2-A27U catalytic core or suboptimal helix Ia pairing, for example, would stimulate the rate of Prp2p-mediated rejection (i), which would proceed faster than the productive step (ii), perhaps simply 
because the catalytic core is less stable. Indeed, we expect that the U2-A27U mutation would destabilize U2/U6 helix I by disrupting the base pair with U6-U57, and we know that U2-A27U suppresses the prp2-Q423N mutation (Fig. 3D), consistent with the U2 mutation accelerating or facilitating Prp2p function.

Evidence suggests that Prp16p- and Prp22p-mediated rejection is reversible, enabling re-sampling of the substrate for optimal sites (Mayas et al. 2006; Koodathingal et al. 2010). Similarly, Prp2p-mediated rejection of the catalytic core may enable further attempts at assembly of a stable and/or productive core (vi) and thereby function akin to an RNP chaperone. Although Prp16p- and Prp22p-mediated rejection may be reversible, rejection can also lead to irreversible discard by the DExD/H-box ATPase Prp43p, which results in release of the substrate and disassembly of the spliceosome (Pandit et al. 2006; Koodathingal et al. 2010; Mayas et al. 2010). Interestingly, Prp43p can bind to the spliceosome not only after Prp16p and Prp22p function but also after Prp2p functions (Chen et al. 2012). Thus, Prp2p-mediated rejection (i) may similarly lead to discard by Prp43p (v). Regardless, our data provide evidence that Prp2p destabilizes U2/U6 helix I not only to advance the spliceosome along the productive pathway but also to proofread formation of the catalytic core.

\section{MATERIALS AND METHODS}

\section{Yeast strains and plasmids}

For the screen for cold-sensitive alleles of $P R P 2$, for primer extension assays, and for growth assays testing U2 and U6 mutations, we used the shuffle strain yJPS1393, which was generated from the previously described strain yHM118 (Madhani and Guthrie 1994b) by transforming it with the plasmid pPRP2U2U6-URA3 (pJPS2503) and then deleting PRP2 with KanMx4. The plasmid pJPS2503 was generated by cloning a PRP2-containing SmaI/SacI fragment into the SmaI site of the previously described pU2U6URA3 (Madhani and Guthrie 1994b). Variants of the plasmid pJPS2500 (pPRP2-pASZ11) were used to screen for cold-sensitive alleles of prp2. pJPS2500 was generated by cloning the PRP2-containing BamHI fragment from pRS415-PRP2 (Edwalds-Gilbert et al. 2000) into the BamHI site of pASZ11 (Stotz and Linder 1990). Variants were generated by QuikChange site-directed mutagenesis (Agilent) and confirmed by sequencing.

For growth assays testing mutations in Prp9p, RES factors, and NTC-related factors, isogenic strains were made from the previously described prp $2 \Delta$ strain YTY1 (Edwalds-Gilbert et al. 2000) by deleting with KanMx4 the gene for either PRP9 (yJPS1416 and yJPS1417), PML1 (yJPS1421), BUD13 (yJPS1418), SNU17 (yJPS1419), CWC27 (yJPS1422), PRP17 (yJPS1423), or ISY1 (yJPS1420). yJPS1416 contains PRP9-pRS313 (pJPS2504), while yJPS1417 contains prp9-1pRS313 (pJPS2505); to generate pJPS2504 and pJPS2505, PRP9or prp9-1-containing BamHI fragments were amplified, respectively, from the previously described strains SS330 and SRY9-1c (Ruby et al. 1993) and cloned into the BamHI site of pRS313 (Sikorski and Hieter 1989). A PML1-containing EcoRI fragment was amplified from ge- nomic DNA from the strain BY4741 (Open Biosystems) and cloned into the EcoRI site of pRS313 to generate pJPS2530. The PML1 variants pml1-R108A (pJPS2532) and pml1-S137A (pJPS2533) were generated by QuikChange mutagenesis and confirmed by sequencing. Variants of PRP2-pRS415 (Edwalds-Gilbert et al. 2000) that were used in these strains were generated by QuikChange mutagenesis and confirmed by sequencing. See the Supplemental Data for a complete list of yeast strains (Supplemental Table S1) and plasmids (Supplemental Table S2) used in this study.

\section{Growth assays}

To screen for interactions between prp2-Q548N and snRNA mutations, variants of pJPS2500 (PRP2-pASZ11), pJPS216 (Hilliker and Staley 2004), and pSX6 (Madhani and Guthrie 1992) were cotransformed into yJPS1393. Transformants were streaked in triplicate onto 5-FOA (5-fluoroorotic acid)-containing media and grown for $3-5 \mathrm{~d}$ at $30^{\circ} \mathrm{C}$ to counterselect against strains with the pU2U6PRP2-URA3 plasmid (Boeke et al. 1987). Colonies were streaked onto YPDA (yeast peptone dextrose adenine) media and grown for $3 \mathrm{~d}$ at $30^{\circ} \mathrm{C}$. The purified colonies were grown in liquid YPDA to an $\mathrm{OD}_{600}$ of $\sim 0.8$ and then spotted onto solid YPDA media. Cells were grown at the permissive temperature of $30^{\circ} \mathrm{C}$ for $2-3$ $\mathrm{d}$ and the restrictive temperature of $15^{\circ} \mathrm{C}$ for $10-16 \mathrm{~d}$ for phenotypic analysis. Yeast cells were transformed by a standard lithium acetate method (Ito et al. 1983).

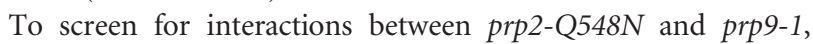

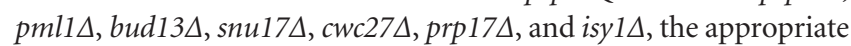
double deletion strain or YTY1 was transformed with variants of PRP2-pRS415. Transformants were streaked onto 5-FOA, colonypurified on YPDA, and spotted onto solid media as above. To test for interactions with prp2-Q548N and putative phosphate binding mutations in PML1, pJPS2530 variants were cotransformed with PRP2-pRS415, prp2-Q548N-pRS415, or prp2-Q548E-pRS415; plasmid shuffle and phenotypic analysis were performed on solid media lacking histidine to maintain the PML1-pRS313 plasmids.

The mutual suppression of prp2-Q548N and U2-A27U and -A27C, which was observed in a pseudo-diploid also expressing wild-type U2, and the rescue of lethality of U2-A27U and -A27G by $\operatorname{prp} 2-Q 548 \mathrm{~N}$, in a true haploid, were revealed using strains derived from yJPS1393 that carried either PRP2-pASZ11 or prp2Q548N-pASZ11 and pU2U6-URA3 (Madhani and Guthrie 1994a). These strains were transformed with pJPS216 variants and pSX6 variants and selected on media lacking histidine, tryptophan, and uracil for the pseudo-diploid experiment and on media lacking histidine and tryptophan for the haploid experiment. For the haploid experiment, transformants were colony-purified on media lacking histidine and tryptophan to give them the opportunity to lose the pU2U6PRP2-URA3 plasmid and then streaked onto media containing 5-FOA and grown for $4 \mathrm{~d}$ at $30^{\circ} \mathrm{C}$.

\section{Primer extension analysis}

Cells were grown to $\log$ phase at $30^{\circ} \mathrm{C}$, whole-cell RNA was harvested from half the cell culture for the permissive temperature samples, and RNA was harvested from the remaining half after a temperature shift for $4 \mathrm{~h}$ to $15^{\circ} \mathrm{C}$. Whole-cell RNA was isolated by hot phenol extraction, and primer extensions were performed as described (Stevens et al. 2002) using ${ }^{32} \mathrm{P}$-end-labeled primers complementary 
to the $3^{\prime}$ exons of $S N R 17 A$ and $S N R 17 B$, which encode U3 snoRNA (5'-CCAAGTTGGATTCAGTGGCTC- ${ }^{\prime}$ ) (Dobbyn and O'Keefe 2004), and to SNR128, which encodes U14 snoRNA (5'-ACGAT GGGTTCGTAAGCGTACTCCTACCGTGG-3') (Hilliker and Staley 2004). Products were separated on a 6\% denaturing polyacrylamide gel, developed by PhosphorImager, and quantitated by Image J (NIH).

\section{SUPPLEMENTAL MATERIAL}

Supplemental material is available for this article.

\section{ACKNOWLEDGMENTS}

We thank current members of the Staley laboratory for helpful discussions and comments on the manuscript; Christine Guthrie, R.-J. Lin, and Stephanie Ruby for yeast strains and plasmids; and Channon Jordan and Martha Norman for technical assistance. This work was supported by a grant from the NIH (GM62264) to J.P.S., and A.M.W. was supported by an NIH training grant (T32 GM007183).

Received September 23, 2013; accepted October 30, 2013.

\section{REFERENCES}

Agafonov DE, Deckert J, Wolf E, Odenwälder P, Bessonov S, Will CL, Urlaub H, Lührmann R. 2011. Semiquantitative proteomic analysis of the human spliceosome via a novel two-dimensional gel electrophoresis method. Mol Cell Biol 31: 2667-2682.

Anokhina M, Bessonov S, Miao Z, Westhof E, Hartmuth K, Lührmann R. 2013. RNA structure analysis of human spliceosomes reveals a compact $3 \mathrm{D}$ arrangement of snRNAs at the catalytic core. EMBO J 32: 2804-2818.

Arenas JE, Abelson JN. 1993. The Saccharomyces cerevisiae PRP21 gene product is an integral component of the prespliceosome. Proc Natl Acad Sci 90: 6771-6775.

Ares M, Igel AH. 1990. Lethal and temperature-sensitive mutations and their suppressors identify an essential structural element in U2 small nuclear RNA. Genes Dev 4: 2132-2145.

Bessonov S, Anokhina M, Will CL, Urlaub H, Lührmann R. 2008. Isolation of an active step I spliceosome and composition of its RNP core. Nature 452: 846-850.

Boeke JD, Trueheart J, Natsoulis G, Fink GR. 1987. 5-fluoroorotic acid as a selective agent in yeast molecular genetics. Methods Enzymol 154: $164-175$.

Brooks MA, Dziembowski A, Quevillon-Cheruel S, Henriot V, Faux C, van Tilbeurgh H, Séraphin B. 2009. Structure of the yeast Pmll splicing factor and its integration into the RES complex. Nucleic Acids Res 37: 129-143.

Brow DA, Guthrie C. 1988. Spliceosomal RNA U6 is remarkably conserved from yeast to mammals. Nature 334: 213-218.

Burgess SM, Guthrie C. 1993a. A mechanism to enhance mRNA splicing fidelity: The RNA-dependent ATPase Prp16 governs usage of a discard pathway for aberrant lariat intermediates. Cell 73: 1377-1391.

Burgess SM, Guthrie C. 1993b. Beat the clock: Paradigms for NTPases in the maintenance of biological fidelity. Trends Biochem Sci 18: 381-384.

Chen HC, Tseng C-K, Tsai RT, Chung CS, Cheng S-C. 2012. A link of NTR-mediated spliceosome disassembly with DEAH-box ATPases Prp2, Prp16 and Prp22. Mol Cell Biol 33: 514-525.

Chiu Y-F, Liu Y-C, Chiang T-W, Yeh T-C, Tseng C-K, Wu N-Y, Cheng S-C. 2009. Cwc25 is a novel splicing factor required after
Prp2 and Yju2 to facilitate the first catalytic reaction. Mol Cell Biol 29: $5671-5678$.

Crawford DJ, Hoskins AA, Friedmanc LJ, Gellesc J, Moore MJ. 2013. Single-molecule colocalization FRET evidence that spliceosome activation precedes stable approach of $5^{\prime}$ splice site and branch site. Proc Natl Acad Sci 110: 6783-6788.

Dobbyn HC, O'Keefe RT. 2004. Analysis of Snu13p mutations reveals differential interactions with the U4 snRNA and U3 snoRNA. RNA 10: 308-320.

Durocher D, Henckel J, Fersht AR, Jackson SP. 1999. The FHA domain is a modular phosphopeptide recognition motif. Mol Cell 4: 387-394.

Dziembowski A, Ventura A-P, Rutz B, Caspary F, Faux C, Halgand F, Laprévote O, Séraphin B. 2004. Proteomic analysis identifies a new complex required for nuclear pre-mRNA retention and splicing. EMBO J 23: 4847-4856.

Edwalds-Gilbert G, Kim D-H, Kim S-H, Tseng Y-H, Yu Y, Lin R-J. 2000. Dominant negative mutants of the yeast splicing factor Prp2 map to a putative cleft region in the helicase domain of $\mathrm{DExD} / \mathrm{H}$-box proteins. RNA 6: 1106-1119.

Fabrizio P, Abelson J. 1992. Thiophosphates in yeast U6 snRNA specifically affect pre-mRNA splicing in vitro. Nucleic Acids Res 20: 3659-3664.

Fabrizio P, Dannenberg J, Dube P, Kastner B, Stark H, Urlaub H, Lührmann R. 2009. The evolutionarily conserved core design of the catalytic activation step of the yeast spliceosome. Mol Cell 36: 593-608.

Fica SM, Tuttle N, Novak T, Li N-S, Lu J, Koodathingal P, Dai Q, Staley JP, Piccirilli JA. 2013. RNA catalyses nuclear pre-mRNA splicing. Nature 503: 229-234.

Fleckner J, Zhang M, Valcarcel J, Green MR. 1997. U2AF ${ }^{65}$ recruits a novel human DEAD box protein required for the U2 snRNPbranchpoint interaction. Genes Dev 11: 1864-1872.

Galej WP, Oubridge C, Newman AJ, Nagai K. 2013. Crystal structure of Prp8 reveals active site cavity of the spliceosome. Nature 493: 638-643.

Gozani O, Feld R, Reed R. 1996. Evidence that sequence-independent binding of highly conserved U2 snRNP proteins upstream of the branch site is required for assembly of spliceosomal complex A. Genes Dev 10: 233-243.

Gozani O, Potashkin J, Reed R. 1998. A potential role for U2AF-SAP 155 interactions in recruiting U2 snRNP to the branch site. Mol Cell Biol 18: $4752-4760$

Hilliker AK, Staley JP. 2004. Multiple functions for the invariant AGC triad of U6 snRNA. RNA 10: 921-928.

Hilliker AK, Mefford MA, Staley JP. 2007. U2 toggles iteratively between the stem IIa and stem IIc conformations to promote pre-mRNA splicing. Genes Dev 21: 821-834.

Ito H, Fukuda Y, Murata K, Kimura A. 1983. Transformation of intact yeast cells treated with alkali cations. J Bacteriol 153: $163-168$.

Jones MH, Frank DN, Guthrie C. 1995. Characterization and functional ordering of Slu7p and Prp17p during the second step of pre-mRNA splicing in yeast. Proc Natl Acad Sci 92: 9687-9691.

Kim SH, Lin RJ. 1993. Pre-mRNA splicing within an assembled yeast spliceosome requires an RNA-dependent ATPase and ATP hydrolysis. Proc Natl Acad Sci 90: 888-892.

Kim SH, Lin RJ. 1996. Spliceosome activation by PRP2 ATPase prior to the first transesterification reaction of pre-mRNA splicing. Mol Cell Biol 16: 6810-6819.

Kim DH, Rossi JJ. 1999. The first ATPase domain of the yeast 246-kDa protein is required for in vivo unwinding of the U4/U6 duplex. RNA 5: 959-971.

Kim SH, Smith J, Claude A, Lin RJ. 1992. The purified yeast pre-mRNA splicing factor PRP2 is an RNA-dependent NTPase. EMBO J 11: 2319-2326.

King DS, Beggs JD. 1990. Interactions of PRP2 protein with pre-mRNA splicing complexes in Saccharomyces cerevisiae. Nucleic Acids Res 18: 6559-6564. 
Kistler AL, Guthrie C. 2001. Deletion of MUD2, the yeast homolog of U2AF65, can bypass the requirement for Sub2, an essential spliceosomal ATPase. Genes Dev 15: 42-49.

Konarska M, Vilardell J, Query C. 2006. Repositioning of the reaction intermediate within the catalytic center of the spliceosome. $\mathrm{Mol}$ Cell 21: 543-553.

Koodathingal P, Staley JP. 2013. Splicing fidelity: DEAD/H-box ATPases as molecular clocks. RNA Biol 10: 1073-1079.

Koodathingal P, Novak T, Piccirilli JA, Staley JP. 2010. The DEAH box ATPases Prp 16 and Prp 43 cooperate to proofread 5' splice site cleavage during pre-mRNA splicing. Mol Cell 39: 385-395.

Krishnan R, Blanco MR, Kahlscheuer ML, Abelson J, Guthrie C, Walter NG. 2013. Biased Brownian ratcheting leads to pre-mRNA remodeling and capture prior to first-step splicing. Nat Struct Mol Biol 20: 1450-1457.

Lardelli RM, Thompson JX, Yates JR, Stevens SW. 2010. Release of SF3 from the intron branchpoint activates the first step of pre-mRNA splicing. RNA 16: 516-528.

Legrain P, Choulika A. 1990. The molecular characterization of PRP6 and PRP9 yeast genes reveals a new cysteine/histidine motif common to several splicing factors. EMBO J 9: 2775-2781.

Lin P-C, Xu R-M. 2012. Structure and assembly of the SF3a splicing factor complex of U2 snRNP. EMBO J 31: 1579-1590.

Linder P, Jankowsky E. 2011. From unwinding to clampingthe DEAD box RNA helicase family. Nat Rev Mol Cell Biol 12: 505-516.

Liu HL, Cheng S-C. 2012. The interaction of Prp2 with a defined region of the intron is required for the first splicing reaction. Mol Cell Biol 32: 5056-5066.

Liu L, Query CC, Konarska MM. 2007a. Opposing classes of prp8 alleles modulate the transition between the catalytic steps of pre-mRNA splicing. Nat Struct Mol Biol 14: 519-526.

Liu Y, Chen H, Wu N, Cheng S. 2007b. A novel splicing factor, Yju2, is associated with NTC and acts after Prp2 in promoting the first catalytic reaction of pre-mRNA splicing. Mol Cell Biol 27: 54035413.

Madhani HD, Guthrie C. 1992. A novel base-pairing interaction between U2 and U6 snRNAs suggests a mechanism for the catalytic activation of the spliceosome. Cell 71: 803-817.

Madhani HD, Guthrie C. 1994a. Genetic interactions between the yeast RNA helicase homolog Prp16 and spliceosomal snRNAs identify candidate ligands for the Prp16 RNA-dependent ATPase. Genetics 137: 677-687.

Madhani HD, Guthrie C. 1994b. Randomization-selection analysis of snRNAs in vivo: Evidence for a tertiary interaction in the spliceosome. Genes Dev 8: 1071-1086.

Mayas R, Maita H, Staley J. 2006. Exon ligation is proofread by the DExD/H-box ATPase Prp22p. Nat Struct Mol Biol 13: 482-490.

Mayas RM, Maita H, Semlow DR, Staley JP. 2010. Spliceosome discards intermediates via the DEAH box ATPase Prp43p. Proc Natl Acad Sci 107: 10020-10025.

McGrail J, Krause A, O'Keefe R. 2009. The RNA binding protein Cwc2 interacts directly with the U6 snRNA to link the nineteen complex to the spliceosome during pre-mRNA splicing. Nucleic Acids Res 37: 4205-4217.

McPheeters DS. 1996. Interactions of the yeast U6 RNA with the premRNA branch site. RNA 2: 1110-1123.

McPheeters DS, Muhlenkamp P. 2003. Spatial organization of proteinRNA interactions in the branch site- $3^{\prime}$ splice site region during premRNA splicing in yeast. Mol Cell Biol 23: 4174-4186.

Mefford MA, Staley JP. 2009. Evidence that U2/U6 helix I promotes both catalytic steps of pre-mRNA splicing and rearranges in between these steps. RNA 15: 1386-1397.

Ohrt T, Prior M, Dannenberg J, Odenwälder P, Dybkov O, Rasche N, Schmitzová J, Gregor I, Fabrizio P, Enderlein J, et al. 2012. Prp2-mediated protein rearrangements at the catalytic core of the spliceosome as revealed by dcFCCS. RNA 18: 1244-1256.

Ohrt T, Odenwälder P, Dannenberg J, Prior M, Warkocki Z, Schmitzová J, Karaduman R, Gregor I, Enderlein J, Fabrizio P, et al. 2013. Molecular dissection of step 2 catalysis of yeast premRNA splicing investigated in a purified system. RNA 19: 902-915.

Pandit S, Lynn B, Rymond BC. 2006. Inhibition of a spliceosome turnover pathway suppresses splicing defects. Proc Natl Acad Sci 103: 13700-13705.

Pena V, Rozov A, Fabrizio P, Lührmann R, Wahl MC. 2008. Structure and function of an RNase $\mathrm{H}$ domain at the heart of the spliceosome. EMBO J 27: 2929-2940.

Perriman RJ, Ares M. 2007. Rearrangement of competing U2 RNA helices within the spliceosome promotes multiple steps in splicing. Genes Dev 21: 811-820.

Perriman R, Ares M. 2010. Invariant U2 snRNA nucleotides form a stem loop to recognize the intron early in splicing. Mol Cell 38: 416-427.

Perriman R, Barta I, Voeltz GK, Abelson J, Ares M. 2003. ATP requirement for Prp5 $\mathrm{p}$ function is determined by Cus $2 \mathrm{p}$ and the structure of U2 small nuclear RNA. Proc Natl Acad Sci 100: 13857-13862.

Putnam AA, Jankowsky E. 2013. DEAD-box helicases as integrators of RNA, nucleotide and protein binding. Biochim Biophys Acta 1829: 884-893.

Query C, Konarska M. 2004. Suppression of multiple substrate mutations by spliceosomal prp8 alleles suggests functional correlations with ribosomal ambiguity mutants. Mol Cell 14: 343-354.

Query CC, Konarska MM. 2012. CEF1/CDC5 alleles modulate transitions between catalytic conformations of the spliceosome. RNA 18: 1001-1013.

Query CC, Strobell SA, Sharp PA. 1996. Three recognition events at the branch-site adenine. EMBO J 15: 1392-1402.

Rasche N, Dybkov O, Schmitzová J, Akyildiz B, Fabrizio P, Lührmann R. 2012. Cwc2 and its human homologue RBM22 promote an active conformation of the spliceosome catalytic centre. EMBO J 31: $1591-1604$

Ritchie DB, Schellenberg MJ, Gesner EM, Raithatha SA, Stuart DT, Macmillan AM. 2008. Structural elucidation of a PRP8 core domain from the heart of the spliceosome. Nat Struct Mol Biol 15: 1199_ 1205.

Roy J, Kim K, Maddock JR, Anthony JG, John L Woolford J. 1995. The final stages of spliceosome maturation require Spp2p that can interact with the DEAH box protein Prp2p and promote step 1 of splicing. RNA 1: 375-390.

Ruby SW, Chang TH, Abelson J. 1993. Four yeast spliceosomal proteins (PRP5, PRP9, PRP11, and PRP21) interact to promote U2 snRNP binding to pre-mRNA. Genes Dev 7: 1909-1925.

Sashital D, Cornilescu G, Butcher S. 2004. U2-U6 RNA folding reveals a group II intron-like domain and a four-helix junction. Nat Struct Mol Biol 11: 1237-1242.

Schmitzová J, Rasche N, Dybkov O, Kramer K, Fabrizio P, Urlaub H, Lührmann R, Pena V. 2012. Crystal structure of Cwc2 reveals a novel architecture of a multipartite RNA-binding protein. EMBO J 31: 2222-2234.

Schneider S, Campodonico E, Schwer B. 2004. Motifs IV and V in the DEAH box splicing factor Prp22 are important for RNA unwinding, and helicase-defective Prp22 mutants are suppressed by Prp8. J Biol Chem 279: 8617-8626.

Schwer B. 2008. A conformational rearrangement in the spliceosome sets the stage for Prp22-dependent mRNA release. Mol Cell 30: 743-754.

Schwer B, Guthrie C. 1992. A conformational rearrangement in the spliceosome is dependent on PRP16 and ATP hydrolysis. EMBO J 11: 5033-5039.

Semlow DR, Staley JP. 2012. Staying on message: Ensuring fidelity in pre-mRNA splicing. Trends Biochem Sci 37: 263-273.

Sikorski RS, Hieter P. 1989. A system of shuttle vectors and yeast host strains designed for efficient manipulation of DNA in Saccharomyces cerevisiae. Genetics 122: 19-27.

Silverman EJ, Maeda A, Wei J, Smith P, Beggs JD, Lin R-J. 2004 Interaction between a G-patch protein and a spliceosomal DEXD/ H-box ATPase that is critical for splicing. Mol Cell Biol 24: 1010110110 
Smith DJ, Konarska MM, Query CC. 2009. Insights into branch nucleophile positioning and activation from an orthogonal pre-mRNA splicing system in yeast. Mol Cell 34: 333-343.

Staley J, Guthrie C. 1999. An RNA switch at the $5^{\prime}$ splice site requires ATP and the DEAD box protein Prp28p. Mol Cell 3: 55-64.

Stevens SW, Ryan DE, Ge HY, Moore RE, Young MK, Lee TD, Abelson J. 2002. Composition and functional characterization of the yeast spliceosomal penta-snRNP. Mol Cell 9: 31-44.

Stotz A, Linder P. 1990. The ADE2 gene from Saccharomyces cerevisiae: Sequence and new vectors. Gene 95: 91-98.

Sun JS, Manley JL. 1995. A novel U2-U6 snRNA structure is necessary for mammalian mRNA splicing. Genes Dev 9: 843-854.

Teigelkamp S, McGarvey M, Plumpton M, Beggs JD. 1994. The splicing factor PRP2, a putative RNA helicase, interacts directly with premRNA. EMBO J 13: 888-897.

Toor N, Keating K, Taylor S, Pyle A. 2008. Crystal structure of a selfspliced group II intron. Science 320: 77-82.

Trowitzsch S, Weber G, Lührmann R, Wahl MC. 2009. Crystal structure of the Pmllp subunit of the yeast precursor mRNA retention and splicing complex. J Mol Biol 385: 531-541.

Tseng C-K, Liu H-L, Cheng S-C. 2010. DEAH-box ATPase Prp16 has dual roles in remodeling of the spliceosome in catalytic steps. RNA 17: $145-154$.

Turner IA, Norman C, Churcher MJ, Newman AJ. 2006. Dissection of Prp8 protein defines multiple interactions with crucial RNA sequences in the catalytic core of the spliceosome. RNA 12: 375-386.

Villa T, Guthrie C. 2005. The Isylp component of the NineTeen complex interacts with the ATPase Prp16p to regulate the fidelity of premRNA splicing. Genes Dev 19: 1894-1904.

Wahl MC, Will CL, Lührmann R. 2009. The spliceosome: Design principles of a dynamic RNP machine. Cell 136: 701-718.

Wang C, Chua K, Seghezzi W, Lees E, Gozani O, Reed R. 1998. Phosphorylation of spliceosomal protein SAP 155 coupled with splicing catalysis. Genes Dev 12: 1409-1414.
Warkocki Z, Odenwälder P, Schmitzová J, Platzmann F, Stark H, Urlaub H, Ficner R, Fabrizio P, Lührmann R. 2009. Reconstitution of both steps of Saccharomyces cerevisiae splicing with purified spliceosomal components. Nat Struct Mol Biol 16: 1237-1243.

Will CL, Schneider C, MacMillan AM, Katopodis NF, Neubauer G, Wilm M, Lührmann R, Query CC. 2001. A novel U2 and U11/ U12 snRNP protein that associates with the pre-mRNA branch site. EMBO J 20: 4536-4546.

Wu J, Manley JL. 1992. Multiple functional domains of human U2 small nuclear RNA: Strengthening conserved stem I can block splicing. Mol Cell Biol 12: 5464-5473.

Xu Y-Z, Query CC. 2007. Competition between the ATPase Prp5 and branch region-U2 snRNA pairing modulates the fidelity of spliceosome assembly. Mol Cell 28: 838-849.

Yang K, Zhang L, Xu T, Heroux A, Zhao R. 2008. Crystal structure of the $\beta$-finger domain of Prp8 reveals analogy to ribosomal proteins. Proc Natl Acad Sci 105: 13817-13822.

Yang F, Wang XY, Zhang ZM, Pu J, Fan YJ, Zhou J, Query CC, Xu Y-Z. 2013. Splicing proofreading at $5^{\prime}$ splice sites by ATPase Prp28p. Nucleic Acids Res 41: 4660-4670.

Yean SL, Wuenschell G, Termini J, Lin RJ. 2000. Metal-ion coordination by U6 small nuclear RNA contributes to catalysis in the spliceosome. Nature 408: 881-884.

Yeh T-C, Liu HL, Chung CS, Wu N-Y, Liu Y-C, Cheng S-C. 2010. Splicing factor Cwc22 is required for the function of Prp2 and for the spliceosome to escape from a futile pathway. Mol Cell Biol 31: 43-53.

Yu Y-T, Maroney PA, Darzynkiewicz E, Nilsen TW. 1995. U6 snRNA function in nuclear pre-mRNA splicing: A phosphorothioate interference analysis of the U6 phosphate backbone. RNA 1: 46-54.

Zavanelli MI, Britton JS, Igel AH, Ares M. 1994. Mutations in an essential U2 small nuclear RNA structure cause cold-sensitive U2 small nuclear ribonucleoprotein function by favoring competing alternative U2 RNA structures. Mol Cell Biol 14: 1689-1697. 

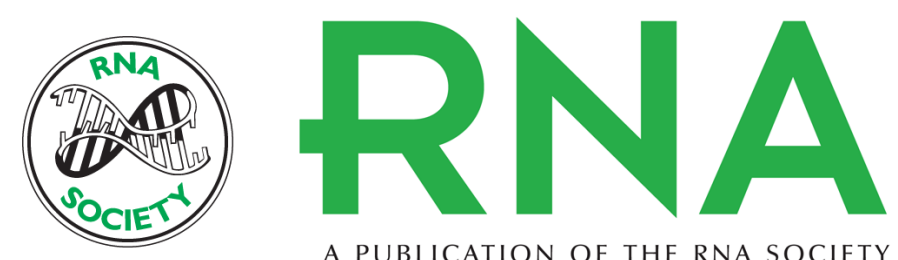

A PUBLICATION OF THE RNA SOCIETY

\section{The DExD/H-box ATPase Prp2p destabilizes and proofreads the catalytic RNA core of the spliceosome}

Alissa M. Wlodaver and Jonathan P. Staley

RNA 2014 20: 282-294 originally published online January 17, 2014

Access the most recent version at doi:10.1261/rna.042598.113

\section{Supplemental http://rnajournal.cshlp.org/content/suppl/2014/01/06/rna.042598.113.DC1 Material}

References This article cites 100 articles, 54 of which can be accessed free at: http://rnajournal.cshlp.org/content/20/3/282.full.html\#ref-list-1

Creative This article is distributed exclusively by the RNA Society for the first 12 months after the Commons License full-issue publication date (see http://rnajournal.cshlp.org/site/misc/terms.xhtml). After 12 months, it is available under a Creative Commons License (Attribution-NonCommercial 3.0 Unported), as described at http://creativecommons.org/licenses/by-nc/3.0/.

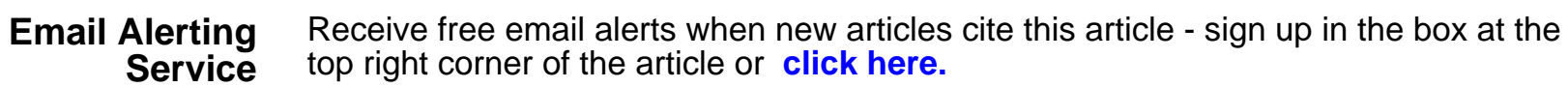

To subscribe to $R N A$ go to:

http://rnajournal.cshlp.org/subscriptions 